S., Brar, D. S. and Hardy, B.), International Rice Research Institute (IRRI), USA, 2003, pp. 3-5.

13. Peng, B. et al., OsAAP6 functions as an important regulator of grain protein content and nutritional quality in rice. Nature Commun., 2014, 5, 4847; doi:10.1038/ncomms5847.

14. Bagchi, T. B., Sharma, S. G. and Chattopadhyay, K., Development of NIRS models to predict protein and amylose content of brown rice and proximate compositions of rice bran. Food Chem., 2015, 191, 21-27; doi:org/10.1016/j.foodchem.2015.05.038.

15. Yang, L. J., Xu, L. and Li, J. Y., Analysis of correlation between protein content, amylose content in the unpolished rice and 1000grain weight in six different varieties' rice. J. Shanghai Normal Univ. (Nat. Sci.), 2004, 10 (Suppl.), 55-58.

16. Yoshida, S., Forno, D. A., Cock, J. H. and Gomez, K. A., Laboratory Manual for Physiological Studies of Rice, IRRI, Manila, Philippines, 1976, 3rd edn, pp. 1-83.

17. Ju, Z., Hettiarachchy, N. and Rath, N., Extraction, denaturation and hydrophobic properties of rice flour proteins. J. Food Sci., 2001, 66, 229-232.

18. Lowry, O. H., Rosebrough, N. J., Lewis Farr, A. and Randall, R J., Protein measurement with the Folin phenol reagent. J. Biol. Chem., 1951, 193, 265.

19. Ufaz, S. and Galili, G., Improving the content of essential amino acids in crop plants: goals and opportunities. Plant Physiol., 2008, 147, 954-961.

20. Pal, P. et al., Effect of nonthermal plasma on physico-chemical, amino acid composition, pasting and protein characteristics of short and long grain rice flour. Food Res. Int., 2016, 81, 50-57.

21. Yan, W. and Kang, M. S., GGE Biplot Analysis: A Graphical Tool for Breeders, Geneticists, and Agronomists, CRC Press, Boca Raton, FL, USA, 2003.

22. DARE Annual Report 2015-2016, Indian Council of Agricultural Research, New Delhi, 2016.

23. Guo, Y., Mu, P., Liu, J., Lu, Y. and Li, Z., QTL mapping and $\mathrm{Q} \times \mathrm{E}$ interaction of grain cooking and nutrient qualities in rice under upland and lowland environments. J. Genet. Genomics, 2007, 34(5), 420-428.

24. Chattopadhyay, K. et al., Detection of stable QTLs for grain protein content in rice (Oryza sativa L.) employing high throughput phenotyping and genotyping platforms. Sci. Rep., 2019, 9, 3196; doi.org/10.1038/s41598-019-39863-2.

ACKNOWLEDGEMENT. We thank the research guidance received from Dr T. Mohapatra, Director General, ICAR and also thank the Director, ICAR-NRRI, Cuttack and the Coordinator of CRP on Biofortification project, ICAR for research funding.

Received 28 May 2017; accepted 6 August 2019

doi: $10.18520 / \mathrm{cs} / \mathrm{v} 117 / \mathrm{i} 10 / 1722-1727$

\section{Utilization of mahua resources: traditional knowledge as a tool for sustainable management}

\author{
H. T. Hegde*, R. P. Gunaga, N. S. Thakur, \\ J. B. Bhusara and R. L. Soundarva \\ College of Forestry, Navsari Agricultural University, \\ Navsari 396 450, India
}

Mahua (Madhuca longifolia var. latifolia Roxb. A. Chev.) tree has religious and aesthetic value in the ethos of many tribes of Gujarat, India. Traditional knowledge of the people about the various uses of mahua is shrinking rapidly due to the change in socioeconomic status. The present study was conducted to draw the utilization pattern of mahua resources and to document the traditional knowledge of the people involved in its usage in Gujarat. Information regarding pattern of utilization and traditional knowledge about mahua was collected using the participatory rural appraisal method. Results highlighted interesting information on traditional knowledge about processing, product development and medicinal value of mahua resources. The species is under threat and receives less care compared to the benefits drawn from it. Therefore, sustainable management of this valuable species is needed by taking a lesson from traditional knowledge.

Keywords: Mahua resources, sustainable management, traditional knowledge, utilization pattern.

MADHUCA longifolia var. latifolia (Mahua) tree has religious and aesthetic value in the ethos of many tribes of Gujarat, India. Since long they have been using mahua resources for food, fermented products, medicine, etc. ${ }^{1-3}$. In the tribal areas of Gujarat, people regularly use mahua seed oil for cooking and for lightening lamps. Mahua flowers are used in various by-products ${ }^{4}$. The estimated production of mahua flowers is more than one million tonnes in the country ${ }^{1}$. Similarly, the annual production of mahua seeds is around 1,085,300 quintals per year, and the prices vary from Rs 1000 to 1500 per quintal ${ }^{5}$. According to a recent report ${ }^{6}$, the total quantity of mahua flowers collected in Gujarat during 2016-17 was 4265 quintals and worth Rs 184.95 lakhs. The total quantity of seeds collected during the same period was 2212.59 quintals and worth of Rs 99.5 lakhs. This clearly shows the dependency of local people on the mahua tree. Populations of mahua are being traditionally protected by local communities, but due to anthropogenic pressure many of mahua population became disturbed sites ${ }^{7}$. Mahua plays an important role in the day-to-day life of tribal people who utilize different parts of this species in various ways.

*For correspondence. (e-mail: hegdeht@gmail.com) 
RESEARCH COMMUNICATIONS

Table 1. Districts and biogeography of the three zones considered in this study

\begin{tabular}{|c|c|c|c|}
\hline Zone no. & Zone & Districts & Biogeography \\
\hline I & Central zone of Gujarat & $\begin{array}{l}\text { Anand, Chhotaudepur, Dahod, Mahisagar, } \\
\text { Panchamahal and Vadodara }\end{array}$ & $\begin{array}{l}\text { Satpuda, Aravali, semi-arid Gujarat, } \\
\text { Rajputana and Coastal Plains }\end{array}$ \\
\hline II & Southeastern zone of Gujarat & Bharuch, Narmada, Surat and Tapi & $\begin{array}{l}\text { Western Ghats, Satpuda, Rajputana and } \\
\text { Coastal Plains }\end{array}$ \\
\hline III & Southern zone of Gujarat & Navsari, Valsad and the Dangs & Western Ghats and Coastal Plains \\
\hline
\end{tabular}

Hence it has great economic importance, especially for tribal communities ${ }^{8}$ and thus needs conservation.

Indigenous knowledge and biodiversity are complementary phenomena essential for human development. To avoid the erosion of rich traditional knowledge, good documentation and mapping of utilization pattern is necessary ${ }^{9}$. In the era of intellectual property rights verbal knowledge cannot be utilized to prevent the misuse of traditional knowledge for granting patents. Only documented traditional knowledge can be helpful to avert biopiracy and unethical patents by big players. Study of utilization pattern of forest products can augment traditional knowledge. The diversity in usage pattern and processing techniques is helpful in developing products for large-scale utilization and may reduce time, energy and cost. Furthermore, documentation of traditional knowledge in the utilization of mahua products is essential to address the consequences and for the sustainable management of mahua resources for ecological, economical and livelihood security. Traditional knowledge of the people about the various uses of mahua is shrinking rapidly due to the change in socio-economic status. The present younger generation of local people is less interested in traditional knowledge $\mathrm{e}^{10}$. There is considerable change in the lifestyle and eating habits of tribal communities, but still wild edible plants are a major source of their diet ${ }^{11}$. Therefore, the present study was conducted to document the utilization pattern of mahua resources in central and southern Gujarat regions, and traditional knowledge of the people involved in its usage. Base-line data generated in the present study may be useful in the management and conservation of mahua resources in $\mathrm{Gu}-$ jarat and the country as a whole.

In order to document the utilization pattern and traditional knowledge about mahua resources, 13 locations were visited during February to June 2017. We documented all the information using participatory rural appraisal method. Table 1 provides details of physical and geographical description of the study area and Figure 1 gives the location of selected villages used in the study. The methodology consists of an interactive learning session from rural people, directly on the site as well as face-to-face, gaining from local physical, technical and social knowledge ${ }^{12}$. Minimum five respondents, who greatly depended on mahua for their livelihood, in the age group between 40 and 60 years, including women respondents, were selected.
Local knowledge about processing, product development, medicinal value and/or utilization of mahua resources was documented during the field survey. Warmed mahua flowers are tied to the affected parts of the body for treatment of swelling and sprain. Traditionally, people use fermented liquid prepared from the first fallen flowers of mahua to effectively treat joint pain. According to ethnomedico-botanical data, all parts of the mahua plant are useful, i.e. leaves control bleeding, bark decoction is used in bleeding gums and ulcers, latex for cracked feet, and seed oil in skin diseases ${ }^{13}$. Bullocks are fed with dried mahua flowers to increase their stamina. Local people also use the conventional method of extraction of kernel from mahua seeds by roller or with the help of a wooden hammer. Mahua oil has a bitter taste. To overcome this, the following techniques are being traditionally practised by the local people: (i) boiling mahua oil with the leaves of Aegle marmelos (bael tree), (ii) boiling the oil with leaves of Syzygium cumini (jamun tree) and pieces of garlic, and (iii) boiling the oil with leaves of Mangifera indica (mango tree). In order to remove impurities, people usually heat mahua oil in a kadai (local pan) with pieces of onion and allow all the impurities to settle down, before domestic use. Therefore, for purification of mahua oil in terms of colour, odour, and taste for edible usage, further refinement is required mainly to get commercial value. Many respondents mentioned that mahua oil cakes obtained after oil extraction are used as organic manure in their agricultural fields. There is traditional knowledge about mahua cake being used as a snake repellent by generating smoke.

People are traditionally aware about the speciality of some genotypes such as high-yielding, higher oil recovery, sweetest flower-bearing tree in the population, etc. Such traditional knowledge would be helpful to screen the better mahua genotypes for further tree improvement programmes and production of quality planting materials.

For an insight of mahua resources in terms of utilization, value-addition and conservation, SWOT parameters, viz. strength, weakness, opportunity and threat were analysed in the present study (Table 2). This information may be helpful for policy makers and forest administrators.

There are many collection and processing challenges for mahua resources. Mainly flowers fall in the late night or early morning; so it is difficult to collect fresh flowers that reduces the quality leading to lower prices. Many a 


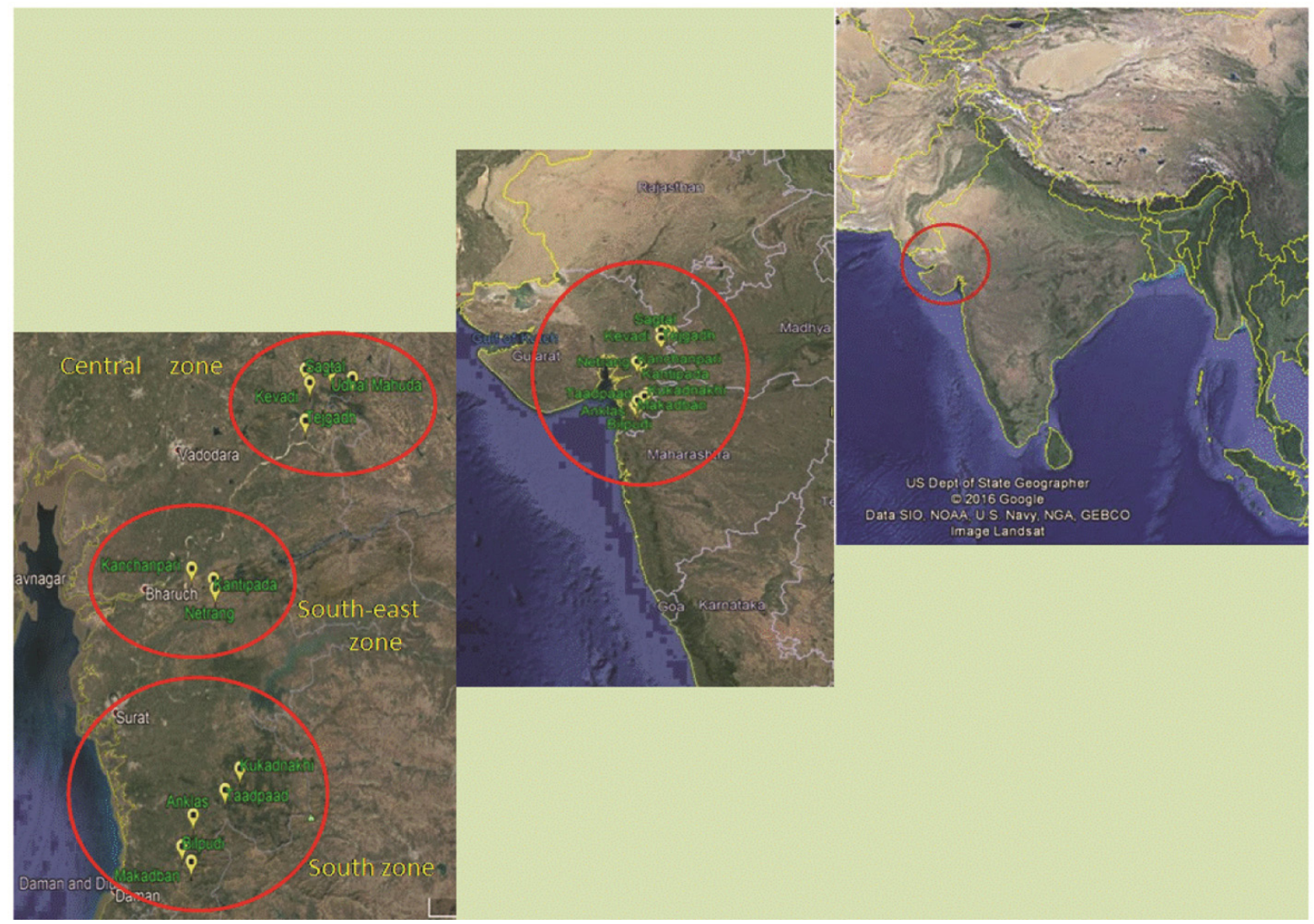

Figure 1. Map showing location of populations of mahua selected during the study period.

Table 2. SWOT analysis of mahua resource management and sustainable utilization

\begin{tabular}{|c|c|c|c|}
\hline Strength & Weakness & Opportunity & Threat \\
\hline $\begin{array}{l}\text { - Important non-wood forest } \\
\text { resource } \\
\text { - Ecological, economic and } \\
\text { social values of the species are } \\
\text { high } \\
\text { - Good market demand for } \\
\text { flowers and seeds } \\
\text { - Profuse flowers and fruits } \\
\text { - Scheduled tree in Gujarat } \\
\text { (high degree of protection) } \\
\text { - Helps maintain } \\
\text { agro-biodiversity } \\
\text { - Provides additional income } \\
\text { opportunity and livelihood } \\
\text { option for the tribal } \\
\text { household. }\end{array}$ & $\begin{array}{l}\text { - It is slow-growing and } \\
\text { there is delay in flowering } \\
\text { and fruit-bearing. } \\
\text { - Mostly ground collection } \\
\text { and collection during } \\
\text { night/early morning. } \\
\text { - Lack of technology availa- } \\
\text { ble for post-harvesting } \\
\text { handling and value- } \\
\text { addition to flowers and } \\
\text { seeds. } \\
\text { - No organized market struc- } \\
\text { ture for sale and highly } \\
\text { fluctuating price. } \\
\text { - Less care and concern } \\
\text { compared to the benefits } \\
\text { drawn. }\end{array}$ & $\begin{array}{l}\text { - Conservation approaches } \\
\text { involving local people by } \\
\text { awareness programmes. } \\
\text { - Screening of better genotypes } \\
\text { for further multiplication. } \\
\text { - Providing technology for } \\
\text { value-addition process and } \\
\text { promotion of entrepreneurship } \\
\text { at local level. } \\
\text { - Domestication of species } \\
\text { through agroforestry/social } \\
\text { forestry. } \\
\text { - Providing fair price to mahua } \\
\text { products by profitable market } \\
\text { mechanisms like market } \\
\text { linkage and Government } \\
\text { interference. }\end{array}$ & $\begin{array}{l}\text { - Unchecked collection and over- } \\
\text { harvesting of mahua products. } \\
\text { - Poor natural regeneration and } \\
\text { lack of young trees in the wild } \\
\text { may lead to reduced yield. } \\
\text { - Most flowers used for the } \\
\text { preparation of fermented } \\
\text { products, rather than the } \\
\text { value-added products. } \\
\text { - Lack of interest among the } \\
\text { younger generation towards } \\
\text { traditional knowledge about the } \\
\text { uses of mahua, its products and } \\
\text { medicinal value, etc. } \\
\text { - Ecological values of the species } \\
\text { are ignored and only economic } \\
\text { benefits are exploited. }\end{array}$ \\
\hline
\end{tabular}

times people stay under the mahua trees at night for flower and fruit collection. Thus they are exposed to attacks by wild animals; snake and scorpion bite, etc. Apart from this, dependency of domestic and wild animals on mahua fruits sometimes results in human animal conflicts. Further, with regard to post-harvest handling, there is no technology or machine available at the local level for de-shelling of the mahua seeds for oil extraction. Drying of kernels is essential before extraction of oil. Lack of drying facility, particularly during rainy season, results in low oil recovery and quality. The process of extraction is conventional and tedious.

For sustainable utilization of mahua resources, documentation of traditional knowledge and its proper application 
are essential along with scientific approaches. Technological and policy interventions are the need of the day to utilize mahua products to their full extent without harming the natural ecosystem. Efforts can be made to give value-addition to traditional knowledge of the local people according to their present needs, which would help enhance their livelihood option. Proper awareness is essential to avoid erosion of traditional knowledge in the wave of modernization. It is the responsibility of the older generation to pass on their traditional knowledge regarding the various uses mahua to the next generation, and this has to be facilitated by institutional approaches.

1. Patel, M. and Naik, S. N., Flowers of Madhuca indica J. F. Gmel., present status and future perspectives. Indian J. Nat. Prod. Resour., 2010, 1(4), 438-443.

2. Orwa, C., Mutua, A., Kindt, R., Jamnadass, R. and Anthony, S., Agroforestry Database: A Tree Reference and Selection Guide version 4.0. World Agroforestry Centre, Kenya, 2009.

3. Fern, K., Madhuca longifolia. Useful Tropical Plants Database, 2014; www.feedipedia.org (accessed on 12 October 2018).

4. Hegde, H. T., Gunaga, R. P., Thakur, N. S. and Sankanur, M. S., Stand structure and regeneration status of mahuva (Madhuca longifolia var. latifolia), an important NWFP species of Gujarat. In Abstract Book of IXX Commonwealth Forestry Conference, Forest Research Institute, Dehradun, 2017, p. 68.

5. Anon., Developing a strategy for forest based livelihoods in Central India through assessment of major NTFP's, Centre for Ecology Development and Research, Dehradun, 2013, p. 62.

6. Anon., Gujarat Forest Statistics, 2016-17, Gujarat Forest Department, Gandhinagar, 2017, p. 34.
7. Hedge, H. T., Gunaga, R. P. and Thakur, N. S., Population structure and regeneration of mahua (Madhuca longifolia var. latifolia (Roxb.) A. Chev.) in disturbed and undisturbed sites. Indian J. Ecol., 2018, 45(4), 724-727.

8. Sikarwar, R. L. S., Mahua (Madhua longifolia (koen.) Macbride), a paradise tree for the tribals of Madhya Pradesh. Indian J. Tradit. Knowl., 2002, 1(1), 87-92.

9. Gavali, D. and Sharma, D., Traditional knowledge and biodiversity conservation in Gujarat. Indian J. Tradit. Knowl., 2004, 3(1), 51-58.

10. Biswas, S. C., Majumdar, M., Das, S. and Misra, T. K., Diversity of wild edible minor fruits used by the ethnic communities of Tripura, India. Indian J. Tradit. Knowl., 2018, 17(2), 282-289.

11. Sharma, L., Samant, S. S., Kumar, A., Lal, M., Devi, K. and Tewari, L. M., Diversity, distribution pattern, endemism and indigenous uses of wild edible plants in Cold Desert Biosphere Reserve of Indian Trans Himalaya. Indian J. Tradit. Knowl., 2018, 17(1), 122-131.

12. Chambers, R., Rural appraisal: rapid, relaxed and participatory. In Participatory Rural Appraisal Methods and Applications in Rural Planning (ed. Mukherjee, A.), Vikas Publishing House Pvt Ltd, New Delhi, 1995, p. 11.

13. Amrithalingam, M., Indian butter tree: ethnobotanical and environmental aspects. MFP News, 2000, 10(2), 9-10.

ACKNOWLEDGEMENTS. We thank Navsari Agricultural University, for providing financial and technical support, and the officers and staff of Gujarat Forest Department for support and permission to conduct the field study. We also thank the local community for cooperation and help during the study.

Received 3 August 2019; accepted 8 August 2019

doi: $10.18520 / \mathrm{cs} / \mathrm{v} 117 / \mathrm{i} 10 / 1727-1730$ 